\title{
LESSONS FROM FINANCIAL ECONOMICS: MATERIALITY, RELIANCE, AND EXTENDING THE REACH OF BASIC $V$. LEVINSON
}

\author{
Jonathan R. Macey* \\ Geoffrey P. Miller** \\ Mark L. Mitchell*** \\ Jeffry M. Netter****
}

\section{INTRODUCTION}

In Basic v. Levinson ${ }^{1}$ the Supreme Court ruled that plaintiffs alleging securities fraud need not prove actual retiance on a defendant's misrepresentations so long as they suffered harm trading in a market shown to be "efficient." In an efficient market, the Court reasoned, informed buyers and sellers drive the price of the security to a level reflecting all publicly available information, ${ }^{2}$ and plaintiffs inay be presumed to rely on the "integrity of the market price" in inaking tlieir trading decisions. ${ }^{3}$ Basic thus establishes inarket efficiency as tlie touchstone of the "fraud-on-the-1narket" tlieory: plaintiffs who traded in an efficient inarket need not prove actual reliance on specific misrepresentations, but their counterparts who traded in an inefficient market must. Whereas Basic in one sense widens tlie scope of the securities fraud action by lowering tlie burden of proof for a particular class of plaintiffs, at the saine time it limits tlie scope by withholding effective legal redress froin anotlier class of plaintiffs, traders in inefficient markets. Further, tlie opimion offers little guidance on the dis-

$\dagger$ We thank Michael Bradley, Dean Furbush, David Jobson, Steve Jones, Stanley Kon, Paul Sequin, participants in seminars at the University of Toronto Law School and Yale Law School, and the editorial staff of the Virginia Law Review for helpful comments.

* J. DuPratt White Professor of Law, Cornell University.

** Kirkland \& Ellis Professor of Law, The University of Chicago.

*** Assistant Professor of Finance, The University of Chicago Graduate School of Business.

**** Assistant Professor of Finance and Adjunct Professor of Law, The University of Georgia.

1485 U.S. 224 (1988).

2 For a discussion of the concept of nuarket efficiency, see infra notes 15-36 and accompanying text.

3 Basic, 485 U.S. at 247. 
tinction between efficient and inefficient markets. Though restricting fraud-on-the-market theory to efficient markets is imtuitively appealing - and indeed few legal commentators have questioned the demarcation, opting imstead to debate what conditions denote efficiency ${ }^{4}-$ we believe this distinction between efficient and inefficient markets to be specious. We suggest that the focus of the Supreme Court's holding in Basic is misplaced: what determines whether investors were justified in relying on the integrity of the market price is not the efficiency of the relevant market but rather whether a misstatement distorted the price of the affected security.

We base our argument on three lessons drawn from a review of numerous empirical studies performed by financial economists. First, substantial disagreement exists about to what degree markets are effcient, how to test for efficiency, and even tlie definition of efficiency. ${ }^{5}$ Second, security prices react quickly to important new information. Finally, a simple empirical technique, called an event study, enables a determination of "whether false information caused a security to trade at an artificially high or low price."6 This determination assumes special importance in light of our conclusion that the criterion relevant to the presumption of rehance is not the efficiency of the market but the occurrence of a material public misstateinent that was reflected in the market price. Whenever event study metliodology shows that a fraudulent event has had a statistically significant effect on the price of a firm's securities, courts are justified im presuming reliance under the fraud-on-the-market theory.

Part II of this Article examines the holding of Basic with particular einphasis on its predicate conception of efficiency. Part III reviews the notion of market efficiency and its relevance for the fraud-on-the-

4 E.g., Carney, The Limits of the Fraud on the Market Doctrine, 44 Bus. Law. 1259, 128687 (1989) (outlining the necessary conditions for market efficiency); Gilson \& Kraakman, The Mechanisms of Market Efficiency, 70 Va. L. Rev. 549, 553 (1984) (discussing "the elements that lead to-and limit-market efficiency"); see also Note, Fraud-on-the-Market Theory After Basic v. Levinson, 74 Cornell L. Rev. 964 (1989) (role of the theory following Basic); Note, Dredging the Shores Doctrine: Trends in the Fraud-on-the-Market Theory in the New Issues Context, $23 \mathrm{Ga}$. L. Rev. 731 (1989) (outlining evolution of the theory).

5 Debate about the implications of the existing empirical evidence for efficiency is robust. See, e.g., Fama, Efficient Capital Markets: II, at 2-5 (1990) (working paper 303 for the Center for Research in Security Prices at the University of Chicago) (copy on file with the Virginia Law Review Association).

6 Fischel, Use of Modern Finance Theory in Securities Fraud Cases Involving Actively Traded Securities, 38 Bus. Law. 1, 17 (1982). 
market theory. In Part IV we describe event study methodology, the empirical technique for determining the impact of a misstatement on a security price. Building on this analysis, we provide in Part V guidelines for identifymg when changes in daily stock returns are large enough to be considered statistically different froin normal, thus suggesting that material firm-specific news reached the market on that day.

\section{The Supreme Court's Application of FinANCe Theory IN BASIC V. LEVINSON}

\section{A. The Basic Definition of Market Efficiency}

Basic v. Levinson involved a suit brought by one-time shareholders in Basic, Incorporated, a pubhicly held firm whose shares were traded on the New York Stock Exchange. Beginning in September, 1976, Basic engaged in merger negotiations with Coinbustion Engineerimg, another large manufacturing firm in a related field. On three separate occasions in 1977 and 1978, officers and directors of Basic issued statements denying that they were involved in merger negotiations. These statements were false. Not only was Basic involved in negotiations, but on December 20,1978, Basic announced that its Board of Directors had approved a tender offer by Combustion Engineerimg for all of Basic's outstanding shares.

Shareholders who sold Basic stock between the time of the first public statement denying merger negotiations and the public announcement of the tender offer brouglit suit claiming that Basic and certain of its officers and directors had violated Rule 10b-5. The plaintiffs alleged that they had suffered injury because they sold their stock at prices "artificially depressed" due to Basic's false and misleading statements about the pendency of serious merger negotiations with Combustion Engineerimg. ${ }^{7}$

In a 10b-5 claim, plaintiffs must normally prove rehance in order to establish the "requisite causal counection between a defendant's misrepresentation and a plaintiff's injury." 8 This reliance requirement often ainounts to a virtually insurmountable burden for plaintiffs if courts require proof of actual rehance on the defendants' specific mis-

7 Basic, 485 U.S. at 228.

8 Id. at 243. 
statements or omissions, ${ }^{9}$ for most security holders rarely read proxy solicitations or annual reports or histen to public corporate announcements.

Aware of the impediments to proving actual reliance, the Court in Basic permitted plaintiffs to invoke the fraud-on-the-market theory to satisfy the 10b-5 rehance requirement. More precisely, the Court endorsed a rebuttable presumption of reliance based on the fraud-onthe-market theory. ${ }^{10}$ As the Court recognized, the fundainental premise underlying the fraud-on-the-market theory is that investors who buy and sell securities are harmed if they rely on the "integrity" of the market price when trading securities whose prices are artificially altered by material misstatements or omissions. The fraud-onthe-market theory thus adopts a market-oriented perspective of the investment decision, emphasizing the role of markets in transmitting information and the irrelevance of most investors' awareness of that information. ${ }^{11}$ This market-oriented perspective mcludes the notion that mvestors who rely on the market price of a security that trades in an efficient market assume all relevant information is incorporated into securities prices and that they need not worry about reading disclosure documents or otherwise researching the particular security they buy. The plaintiffs suffer an imjury by virtue of their reliance on the integrity of a market price that was distorted by false information. ${ }^{12}$

The Court limited its holding, however, stating that in order to obtain the benefit of the presumption of rehance created by the fraudon-the-market theory, plaintiffs must "allege and prove ... that the shares [they bought or sold] were traded on an efficient market."13 The Court felt that rehance on market imtegrity must be reasonable

9 As the Court observed in Basic, the traditional reliance requirenent is a particularly difficult liurdle for plaintiffs in class action law suits: "Requiring proof of individualized rehance froin each ineinber of the proposed plaintiff class effectively would liave prevented respondents from proceeding witl a class action, since individual issues then would have overwhelmed the common ones." Id. at 242 . Class action hitigation is a practical necessity where total dainages are large but the claims of individual plaintiffs are small.

10 Id.

II See generally Fiscliel, supra note 6 (using inodern finance theory to analyze plaintiff injury in securities fraud cases).

12 Id. at 12.

13 Basic, 485 U.S. at 248 n.27. 
and that rehance on the market price of securities that trade in inefficient markets is unreasonable.

\section{B. An Alternative Way of Considering Efficiency for the Fraud-on-the-Market Theory}

This focus on efficiency unnecessarily complicates the inquiry. The Court erred by confusing reliance on the efficiency of the inarket in pricing certain securities witl reliance on the fact that important news will be incorporated quickly into the prices of affected securities. Because security prices react quickly to new information, we can test for the relevant consideration-whether a security's price has been affected by misleading information. Testing for efficiency proves far inore difficult.

The Court's holding in Basic is based on a misunderstanding of the implications of the fact that securities prices quickly incorporate new information. The Court interpreted this evidence to mean that at least soine securities inarkets are efficient. Certainly, evidence that securities prices react quickly to new information supports the hypothesis that markets are efficient. Nevertheless, the implications of this einpirical evidence for efficiency are disputed, and courts need not enter this dispute.

The inquiry relevant to a presumption of reliance in a securities fraud case is not whether the inarket for a security is efficient, but whether the defendants' misstateinents or omissions affected the price of that security. The Court in Basic failed to recognize that inajor false misstateinents or omissions can cause price distortions in any securities market. The well developed empirical techniques of financial economics are 1nuch better suited to determining whether a misstatement affected the market price than to determining the efficiency of the relevant inarket. By determining empirically whetlier a imsstateinent was inaterial-and if so, presuming reliance-we can bypass the vexing inquiry into efficiency. Conversely, if plaintiffs are unable to show that a misstatement was material-that it affected the security price-then the fraud-on-the-1narket theory presumption of rehance should not apply. ${ }^{14}$

14 Defendants may also benefit from the use of event studies im securities fraud litigation, in part because the market is often good at discounting false information. For example, if event studies show that the market discounted certain false statements, defendants can use this 


\section{The Definition of EFFicient MARKets AND ItS RELEVANCE IN SECURITIES LITIGATION}

\section{A. The Efficient Markets Hypothesis}

Our discussion of market efficiency ${ }^{15}$ begins with a definition of stock price under restrictive assumptions: "(1) all investors have costless access to currently available information about the future; (2) all investors are good analysts; and (3) all investors pay close attention to market prices and adjust their holdings appropriately."16 Under these conditions, stock prices are a good estimate of investment value, where investment value is defined as the "present value of the security's future prospects as estimated by well informed and capable analysts."17 Alternatively stated, the price of a stock is equal to the present value of the expected discounted cash flows from the stock to investors who own it. These future cash flows consist of the stream of forecasted dividends and the value of the assets of the firm owned by the shareholders reinaining in the last period. ${ }^{18}$ The price of the stock can then be given by:

$$
\begin{aligned}
P_{0}= & D V_{1} /(1+r)+D V_{2} /(1+r)^{2}+\operatorname{DIV}_{3} /(1+r)^{3}+ \\
& \ldots+\left(D^{2} V_{b}+P_{h}\right) /(1+r)^{h}
\end{aligned}
$$

where:

$\mathbf{P}_{\mathrm{o}}=$ stock price in the current period

$\operatorname{DIV}_{\mathbf{i}}=$ expected dividend in period $\mathbf{i}$

$\mathbf{P}_{\mathrm{h}}=$ expected price of reinaining assets in period $\mathrm{h}$ (final period)

evidence to reduce damages as well as rebut the presumption of reliance. For more on event studies, see Part IV of this Article.

15 The following discussion, as well as the analysis in the remainder of this Article, also applies to valumg otlier seeurities, but for simplicity we use stock prices and returns.

16 G. Alexander \& W. Sliarpe, Fundamentals of Investments 67 (1989). Sharpe wou a Nobel Prize in Economics in 1990.

17 Id.

18 See R. Brealey \& S. Myers, Principles of Corporate Finance 49-52 (3d ed. 1988). For a more fornal approacl, see E. Faina, Foundations of Finance (1976); E. Faina \& M. Miller, The Theory of Finance cl. 2 (1972). The semmal article on dividend policy remains Miller \& Modigliam, Dividend Policy, Growtl and the Valuation of Shares, 34 J. Bus. 411 (1961), which argues that under certain restrictive assumptions the value of the firm is unrelated to the dividend policy of the firm. That is, sharelolders are indifferent between receiving their casl flows as dividends or as capital gains upon reinvestment by the firm of the cash flows back into the firm. Complicating factors tliat affect the influence of dividends on the value of the firm include corporate and personal taxes, agency costs, and infornation heterogeneity. See $T$. Copeland \& J. Weston, Financial Theory and Corporate Policy 544-613 (3d ed. 1988). 

$r=$ expected discount rate, the expected return on other stocks with equal risk.

In this view, a stock price depends on the expected value of three variables: future dividends, the discount rate, and the value of the firm in its final period. ${ }^{19}$ Under the assumptions of constant dividends and an infinitely long-lived firm, this equation simplifies to the perpetuity:

$$
\mathbf{P}_{\mathrm{o}}=\mathrm{DIV} / \mathrm{r} \text {. }
$$

When investors revise their expectations about the values of any of these variables, stock prices adjust correspondingly.

This representation of a stock price facilitates understanding of one frequently used approach to defining efficient markets, one focused on the information incorporated in the price of securities. For instance, one definition of an efficient market is a market "in which every security's price equals its investınent value at all times."20 Similarly, the 1nost common definition calls it a "market in which prices fully reflect available information."21 Under this type of definition, efficiency is characterized by the information set incorporated in stock prices. For example, in a market that is weak-form efficient, stock prices incorporate all information about past prices of securities. Under semistrong efficiency stock prices reflect all publicly available information; strong-form efficiency implies that all information (public and private) is incorporated in stock prices. ${ }^{22}$

The definition of efficiency based on information incorporated in prices can be used to model changes in stock prices. The buying and selling of stocks by investors due to changing expectations from the arrival of new information will result in price adjustment so that all securities with equivalent risk earn the same return. ${ }^{23}$ Once stock prices have inoved to this level, changes in a firm's stock price will

19 Note that earnings reinvestment will result in either higher future dividends or a higher $P_{b}$ than if the earnings are paid out as dividends.

20 G. Alexander \& W. Sharpe, supra note 16 , at 67.

${ }^{21}$ E. Fama \& M. Miller, supra note 18, at 335. Miller won a Nobel Prize in Econounics in 1990.

22 G. Alexander \& W. Sharpe, supra note 16, at 67; see also Macey \& Miller, Good Finance, Bad Economics: An Analysis of the Fraud-on-the-Market Theory, 42 Stan. L. Rev. 1059 (1990) (arguing that the Court in Basic meant semistrong efficiency when discussing efficiency).

${ }^{23}$ See G. Alexander \& W. Sharpe, supra note 16 , at 68 ; R. Brealey \& S. Myers, supra note 18 , at $49-52$. 
occur only when investors receive new information that causes thein to reevaluate the expected cash flows of the firm. ${ }^{24}$

Thus, a basic tenet of this version of the efficient markets theory is that the rational self interest of investors assures "that all relevant and ascertainable information is already reflected in security prices."25 When information about the cash flows of a firm becomes available to investors-who incorporate it into their investment decisions-it is reflected in stock prices. As long as a stock has a close substitute (a portfoho of securities with the saine risk) arbitrage alnong the stock and its substitute portfoho will inove the stock price to the value of its expected cash flows. Because stock prices change only when investors receive new information, which arrives randomly, stock prices change in an unpredictable manner-a randoin walk. ${ }^{26}$

24 See G. Alexander \& W. Sharpe, supra note 16, at 68; S. Ross \& R. Westerfield, Corporate Finance 302-04 (1988). The efficient markets theory hypothesizes that stock prices incorporate all relevant available information. New information that changes expectations will change stock prices; because stock prices already incorporate expectations, prices move only if these expectations change. See R. Brealey \& S. Myers, supra note 18, at 289. Investors do not necessarily need to buy or sell shares to change prices; when current shareholders change the prices at which they are willing to buy or sell, the prices will change.

Stock prices are volatile because "the future is so uncertain and people are so often surprised." Id. For example, suppose a firm unexpectedly introduces a new product that will increase future cash fiows above what was anticipated. The firm's stock price will rise to reflect the higher expected cash flows. (Note that this example would not apply under strongform efficiency because the market would already have known about the new product. If strong-form efficiency holds, only information that is totally new to everyone will move stock prices.)

25 R. Brealey \& S. Myers, supra note 18 , at 282 . This concept springs froin the realization that security prices in one period are imdependent of their prices im other periods, that they follow a "random walk:" See infra note 26 and accompanying text. This idea (although not the term random walk) was first proposed in 1900 by Louis Bachelier, who examined commodity prices in France and concluded that neither buyers nor sellers of commodities could expect to make profits because the best estimate of the future price of a commodity was its present price. Thus, commodity speculation, he felt, was a fair game. Financial economists, lrowever, did not make much use of the concept of a random walk until the 1950s. See generally R. Brealey \& S. Myers, supra note 18, at 281-85 (charting the theory's historieal development); J. Lorie, P. Dodd \& M. Kimpton, The Stock Market: Thcories and Evidence 55-80 (2d ed. 1985) (same).

26 See R. Brealey \& S. Myers, supra note 18, at 285-87, For evidence on the random walk hypothesis, see, e.g., id. at 281-99; T. Copeland \& J. Weston, supra note 18, at 330-400; E. Fama, Efficient Capital Markets: A Review of Theory and Empirical Work, 25 J. Fin. 383 (1970); M. Jensen, Tests of Capital Market Theory and Imphications of the Evidence, in 


\section{B. Implications of the Empirical Evidence on Efficiency for the Fraud-on-the-Market Theory}

Financial economists judge the validity of theories through empirical testing. Though the type and form of the tests of market efficiency are so varied that we will not survey thein here, ${ }^{27}$ we can at a ininimum conclude that substantial disagreenent exists among financial econoinists about what conclusions einpirical tests of market efficiency support. ${ }^{28}$ We suggest, therefore, that the inquiry into effi-

Handbook of Financial Economics 13 (J. Bicksler ed. 1979); S. Ross \& R. Westerfield, supra note 24, at 302-15; Fama, supra note 5.

The discussion of efficiency in the text characterizing efficient inarkets based on prices' incorporating available information does not represent the only way researchers have defined efficiency. Indeed, Professor William Beaver criticizes this definition as tautological. He argues that defining the set of available information as the information fully reflected in prices is circnlar. Beaver, Market Efficiency, 56 Acct. Rev. 23, 27 (1981). Beaver defines a inarket as efficient with respect to specific information "if prices act as if everyone knows the information." Id. at 35. Professor Mark Latham expands this definition by stating that markets are efficient with respect to information set $A$ if and only if revealing $A$ to all traders wonld not alter prices or portfolios. Latham, Informational Efficiency and Information Subsets, 41 J. Fin. 39, 40 (1986). Latham challenges Beaver's definition as mathematically deficient because it does not exhibit the property that efficiency with respect to an information set implies efficiency with respect to any subset of that set, "'subset property, a widely accepted feature of informational efficiency." Id.

Another definition of efficiency focuses on the implications of investment returns. For example, Professor Michael Jensen defines a market as efficient with respect to a set of information if investors cannot make economic profits trading on that information. Jensen, Some Anomalous Evidence Regarding Market Efficiency, 6 J. Fin. Econ. 95, 96 (1978). Professors Richard Brealey and Stewart Myers state that capital markets are efficient if the purchase or sale of any security at the prevailing market price is never a positive net present value project on a risk adjusted basis. R. Brealey \& S. Myers, supra note 18, at 281. All these definitions imply that investors cannot reap above normal profits by trading on stale information.

27 See, e.g., E. Elton \& M. Gruber, Modern Portfolio Theory and Investment Analysis cl. 15 (4th ed. 1991) (reviewing the einpirieal evidence testing market efficiency); Fama, supra note 5 (same); see also De Bondt \& Thaler, A Mean-Reverting Walk Down Wall Strect, $3 \mathrm{~J}$. Econ. Perspectives 189 (Winter 1989) (reviewing evidence testing the predictability of stock prices based on the theory that stock prices are mean reverting).

28 E.g., G. Alexander \& W. Sharpe, supra note 16, at 68 ("the major U.S. security markets appear to be inuch closer to efficiency than to craziness"); E. Elton \& M. Gruber, supra note 27, at 432 ("It is hard to draw definitive conclusions from this literature."); Fama, supra note 5, at 1 ("[c]apital markets are almost surely inefficient"). Professor Eugene Fama has noted that market efficiency cannot be tested by itself because tests of market efficiency are a joint test with a model of equilibrium pricing. Id. at 2.

Not surprisingly, given the unsettled questions of efficiency in the finance literature, legal cominentators liave questioned the usefulness of the efficient markets theories for legal analysis. E.g., Basic, 485 U.S. at 254 (White, J., dissenting): 
ciency is too complex to warrant its use as the basis for a presumption of rehance on the integrity of the market price of a security. Fortunately, this inquiry is also unnecessary.

Fimancial economists "largely agree on the facts that emerge froin the empirical work, even when they disagree about their imphications for efficiency."29 Financial economists have shown repeatedly that stock prices react quickly to the release of important new information; though they may differ in their interpretations of this evidence, they do agree it exists. Even prominent financial economists with divergent interpretations of the evidence on market efficiency share similar views on how stock prices react to new information. Professor Eugene Fama of the University of Chicago states:

In event studies on daily data, the common result is that on average stock prices seem to adjust within a day to event announcements. The result is so common that this work now devotes bittle space to market-efficiency.... [T] he evidence seems to say that, with respect to firm-specific events the adjustment of stock prices to new information is efficient. ${ }^{30}$

Fama continues:

There is a mass of event-study work on issues in corporate finance. The results imdicate that on average stock prices adjust quickly to information about investment decisions, dividend changes, changes in capital structure, and corporate-control transactions. This evidence tilts me strongly toward the conclusion that prices adjust efficiently to firm specific information. ${ }^{31}$

For while the economists' theories which underpin the fraud-on-the-1narket presumption may have the appeal of mathematical exactitude and scientific certainty, they are-in the end-nothing more than theories which may or may not prove accurate upon further consideration.

Others echo this concern. See, e.g., Gordon \& Kornhauser, Efficient Markets, Costly Information, and Securities Research, 60 N.Y.U. L. Rev. 761, 764 (1985) ("We think that the legal rush to embrace and apply the efficient market hypothesis has been overly precipitous and occasionally unwise."); Kraakman, Taking Discounts Seriously: The Implications of "Discounted" Share Prices as an Acquisition Motive, 88 Colum. L. Rev. 891 (1988); Stout, The Unimportance of Being Efficient: An Economic Analysis of Stock Market Pricing and Securities Regulation, 87 Mich. L. Rev. 613 (1988).

29 See Fama, supra note 5, at 2.

30 Id. at 37-38.

31 Id. at 45. 
Professor Lawrence Summers of Harvard University, a leading academic critic of sonıe of the claims of nuarket efficiency, has likewise observed:

Countless studies have demonstrated that stock prices respond almost instantaneously to new information, and that no predictable excess returns can be earned by trading after information has been released. This finding has no power in distinguishing the traditional market efficiency hypothesis from the alternative considered here. Under the alternative hypothesis considered here, the inarket responds immediately to news about fundamentals .... And no abnormal patterns in returns are generated subsequent to major news announcements. The 'fads' hypothesis considered here and the market efficiency hypothesis make exactly the same prediction about true news and so announcement tests do not provide any basis for distinguishing between them. ${ }^{32}$

Our point is that because securities nuarkets react quickly to new information, niaterial misstatenients and omissions will likewise be incorporated. This fact, and not stylized notions of efficiency, constitutes the relevant consideration in determining whether investors should be entitled to rely on the nitegrity of a niarket price. As Fama notes:

Capital markets are almost surely inefficient. The market-efficiency hypothesis, that security prices fully reflect all available information, is an extreme null hypothesis, a point on a continuum, and so almost surely false. The interesting task is not to accept or reject market efficiency but to ineasure the extent to which the behavior of returns departs from its predictions. We can then make informed judgements about the scenarios where market efficiency is a good approximation and those where some other model is a better simplifying view of the world. ${ }^{33}$

Thus the inquiry into inarket efficiency serves inerely as an imperfect proxy for the determination of whether stock prices rapidly incorporate new information. ${ }^{34}$ That concern with the results of this latter

\footnotetext{
32 Summers, Does the Stock Market Rationally Reflect Fundamental Values?, 41 J. Fin. 591, 596 (1986).

33 Fama, supra note 5, at 1.

34 Professors Jonathan Macey and Geoffrey Miller have observed that "the ECMH [Efficient Capital Markets Hypothesis] has not been developed theoretically with nearly the same degree of sophistication as it has been developed einpirically." Macey \& Miller, supra note 22 , at $1059-60$. This is not surprising because the observations preceded the theory:
} 
rather than the former inquiry underhes the Court's opinion in Basic is evident from the following passage:

An investor who buys or sells stock at the price set by the inarket does so in rehance on the integrity of that price. Because most pubhicly available information is reflected in market price, an investor's reliance on any public material misrepresentations, therefore, may be presumed for purposes of a Rule $10 \mathrm{~b}-5$ action. ${ }^{35}$

The Court clearly suggests here that the truly relevant inquiry is, as we propose, whether a inaterial public misstatement has occurred that has distorted the inarket price.

In Part IV we outline the procedure used by financial economists to determine the effect of information on the price of securities. This technique, called an event study, permits the researcher in a securities fraud case to determine whether a misstatement has significantly affected the market price-whether the misstatement was material. If the misstatement was material, it must have affected the integrity of the inarket pricc, and rehance inay then be presumed. ${ }^{36}$

\section{Event Study Methodology}

\section{A. Overview}

Event studies are an empirical technique for determining how securities returns react to new information. ${ }^{37}$ As a result, they can also be used to test the efficient markets hypothesis that stock prices rapidly incorporate new information. Evidence that this does in fact

The efficient market hypothesis had a strange beginning. Generally, a theory is suggested and then extensive tests are undertaken to try to see if it better describes reality than previously accepted theories. The efficient market theory was developed in the opposite way. First, extensive tests were undertaken that demonstrated that, contrary to popular behef, certain types and ways of using imformation (usually past prices) did not lead to superior profits. When evidence along these lines aceumulated, academics went in search of a theory to explain these findings and the efficient market theory was born.

E. Elton \& M. Grnber, supra note 27, at 403.

35 Basic, 485 U.S. at 247.

36 Fischel, supra note 6, at 17-18 (making these arguments).

37 See Brown \& Warner, Using Daily Stock Returns: The Case of Event Studies, 14 J. Fin. Econ. 3 (1985) (comprehensive analysis of event studies); R. Gilson, The Law and Finance of Corporate Acquisitions chs. 5-6 (1986) (discussing the efficient market hypothesis and event study methodology); Henderson, Problems and Solutions in Conducting Event Studies, $57 \mathrm{~J}$. Risk and Ins. 282 (1990) (reviewing event study methodologies and correcting problems that arise with the techniques). 
occur provides support for the efficient markets hypothesis. ${ }^{38}$ As we have suggested, however, it is unnecessary to establish efficiency to justify a presumption of reliance under the fraud-on-the-market theory.

The idea behind event studies is simple. To test whether and how mucli a stock price lias reacted to news, the researclier examines to what extent the return on the stock in the period when the market receives the news (the actual return) differs from what the return would have been without the news (tlie predicted return). This difference is called the abnormal return, and assuming the researcher has correctly identified the news release date and no other firm specific news reaches the market at that time (called a confounding event), the abnormal return indicates the impact of the news on the stock return. ${ }^{39}$ The researcher can statistically test the significance of the abnormal return to determine the likelihood that this abnormal return occurred by chance rather than due to the new information.

The application of event study inethodology to the fraud-on-tliemarket theory is straightforward. A plaintiff need slow only that the misstatement affected the security return-by testing for an abnormal return either at the time the misstatement was made or when the fact that it was a misstatement becaine known to the public - and that the abnormal return was statistically significant. If the abnormal return is found statistically significant, ${ }^{40}$ we suggest that a court should consider tlie misstatement inaterial and presume reliance by a plaintiff on the integrity of the market price. Statistical significance of the abnormal return indicates that the misstatement was incorporated into (and distorted) the inarket price. ${ }^{41}$ Nowhere in this procedure is there a

38 "The cleanest evidence on market-efficiency comes from event studies, especially event studies on daily returns. ... This evidence tilts me strongly toward the conclusion that prices adjust efficiently to firm-specific information." Fama, supra note 5, at 44-45.

39 The size of the abnormal return measures the magnitude of the effect of the information on the stock return; event studies are thus useful in estimating damages im securities fraud cases. See infra note 41 .

40 All else held constant, the larger the abnormal return, the more likely it is statistically significant.

41 Professor Daniel Fischel outlines this concept: "Moreover, by comparing the predicted return with the actual return on the date of release of the supposedly correct information or immediately thereafter, the test attempts to isolate the change in the return earned by investors that is attributable solely to the allegedly withheld or false information." Fischel, supra note 6, at 18. The abnormal return can also be used in damages calculation because it estimates the value of the information contained in the misstatement. See, e.g., Cornell \& Morgan, Using 
need to test for efficiency: the relevant characteristics of the market for the security in question will be accounted for in the coinparison of the actual returns to the predicted return as well as in the statistical test of the significance of the resulting abnormal return.

\section{B. Performing an Event Study}

In this section we outline the basic procedure for performing an event study using daily stock return data. In an actual fraud-on-themarket case, the researcher would adapt this technique shightly to the special factors of the particular case. Nevertheless, researchers have shown that the findings of event studies using different methodologies are robust in a wide variety of situations. ${ }^{42}$ That the findings of event studies using any of a number of methodologies are very similar is especially true when testing for inateriality in a fraud-on-the-market theory case-the effect on stock returns of an important piece of news released over a short period of time.

\section{Choose an Event Window}

Event studies examine the impact of an event on security returns over a discrete period. ${ }^{43}$ The first step im conducting an event study is to select an "event period" that defines the period during which news about the event under study might have had an mipact on the stock price of the company analyzed. Determining the length of an event window involves an important tradeoff. In one respect, long event windows ensure the inclusion of all dates on which new information about the event became available to traders. On the other hand, long event windows raise the likelihood that the company's stock return was affected by other events (confounding events); this makes it difficult to isolate the imdependent effect of the relevant event.

Finance Theory to Measure Damages in Fraud on the Market Cases, 37 UCLA L. Rev. 883, 899-911 (1990).

42 E.g., Brown \& Warner, supra note 37, at 3 (comprehensive study of the impact of potential problems on event study methodology) ("Daily data generally present few difficulties for event studies. Standard procedures are typically well-specified even when special daily data characteristics are ignored.").

43 A return is usually calculated as $\left(P_{\text {new }}-P_{\text {old }}\right) / P_{\text {old. }}$. Because most event studies have been performed on stock returns, we use the terminology of stock returns. Event studies may be used to examine other securities returns. 
The degree of difficulty in defining the event period varies across events. In cases where the relevant information was unanticipated, it is relatively easy to establish the beginning of the event period. Defining the beginning of the event period for events that are at least partially anticipated is more problennatic. Thus, except for events that are completely unanticipated, financial economists inay start the event period on a date that is earlier than the public announceinent date because information about corporate events may "leak" to the inarket before the formal announceinent of the event. ${ }^{44}$

Choosing the end date of an event window is inore straightforward. Because the market absorbs and processes information rapidly, it is conventional to expand the event window only a short period beyond the announceinent of the news; stock prices reflect new information by the close of trading on the day of the public announcement. ${ }^{45}$ When coinputing a stock return due to an event, financial economists often define the event period as the two-day period consisting of the announceinent day and the following day. ${ }^{46}$

In the case of the inateriality requireinent in fraud-on-the-1narket cases, defining the event window is straightforward because we generally know precisely when the misstatement (and/or the revelation of the misstatement) became known to the market. The researclier examines the stock returns in the short period around the release of the public misstateinent or, alternatively, around the public announceinent that thc earlier statement was false.

44 Jarrell \& Poulsen, Stock Trading Before the Announcement of Tender Offers: Insider Trading or Market Anticipation?, 5 J. L. Econ. \& Org. 225 (Fall 1989) (examination of leakage before tender offers leads to finding of a runup in stock prices of $38.8 \%$ of the eventual control premium by the close of trading the day before the public announcement); see also Meulbrock, An Empirical Analysis of Insider Trading and the Stock Market (finding that in firms where the SEC successfully prosecuted insider trading, the price movement in the affected stocks on the day of the insider trades was approximately half the price movement on the day the information became public) (draft copy on file with the Virginia Law Review Association).

45 "The price reaction to news appears to be almost immediate. For example, within 5 to 10 minutes of earnings or dividend announcements appearing on the broad tape, most of the price adjustment has occurred and any remaining gain from acting on the news is less than the transaction costs." R. Brealey \& S. Myers, supra note 18, at 287 n. 10 .

46 The written media, such as the Wall Street Journal, normally reports the announcement the day after the public announcement. Researchers often use a two-day window, where the Wall Street Journal announcement date represents the second day in the window, when they are uncertain whether the public announcement occurred after the close of trading. The development of online news retrieval services now enables researchers to time news releases more precisely and thus use one-day windows more often. 


\section{Calculate Abnormal Returns}

\section{a. Overview}

The next step is to determine whether the stock return in the event window is normal by calculating the abnormal return associated with the event. ${ }^{47}$ Assuming the event window is properly specified and there are no confounding events, ${ }^{48}$ the abnormal return indicates the unpact of the news on the firm's stock return. ${ }^{49}$ The method used to calculate the abnormal return depends on the benchmark used as the normal (predicted) return. For instance, in specifying the normal return, the researcher sometimes coinpares the actual return with the firm's average return during a control period. ${ }^{50}$

When the event window extends for more than one day, the abnormal returns are sumined to obtain the cuinulative abnormal return:

$$
\mathrm{CAR}_{\mathbf{T}}=\sum_{\mathrm{t}}^{\mathrm{T}} \mathrm{AR}_{\mathrm{t}}
$$

where $T$ is the length of the event window. $C R_{T}$ measures the total impact of the event on the stock return. Generally, event studies report both the daily $\mathrm{AR}_{\mathrm{t}}$ and the $\mathrm{CAR}_{\mathrm{T}}$ over the event window. For long event windows, where there is gradual leakage of new information, the $\mathrm{CAR}_{\mathrm{T}}$ is usually emphasized. The $\mathrm{AR}_{t}$ is a "clean" measure only when unanticipated information is released clearly and distinctly. We suggest above, however, that for the inateriality requirements of the fraud-on-the-market theory, the researcher would generally use a short event window.

If the abnormal return is large and the moinent of the information release can be identified fairly precisely-as occurs in most apphications of the fraud-on-the-market theory-the exact techmique used to

47 See Henderson, supra note 37 , at 284-85 (detailing ways to characterize the expected returns).

48 It is important to determine whether other news affected the firm during the event window. Different ways exist to account for such confounding news. Below, for example, we show how to account for marketwide news. See infra notes 54-59 and accompanying text.

49 The simplest way of aggregating daily abnormal returns over the event window is to combine the daily abnormal returns into a cumulative abnormal return (CAR).

so We use this approach in estimating a few guidelines for statistically significant returns in Part V. 
estimate abnormal returns makes little practical difference. ${ }^{51}$ Fama summarizes this conclusion:

When an information event can be dated precisely and the event has a large effect on prices, the way one abstracts from expected returns to measure abnormal daily returns is a second-order consideration. As a result, event studies can give a clear picture of the speed of adjustment of prices to information. ${ }^{52}$

Professors Steplien Brown and Jerold Warner, in their article analyzing the feasibility of using different event study methodologies to deal with different types of problems, conclude that simple event study procedures are generally effective: "[Our] results indicate a striking similarity between the empirical power of the event study procedures and the theoretical power implied by a few simple assumptions and 'back of the envelope' calculations. This reinforces the view that the use of daily data is straiglitforward." 53

\section{b. Accounting for Marketwide Influences on Stock Returns}

Because stock returns vary witlı general market movements, it is sometimes beneficial to distinguislı returns attributable to marketwide influences (e.g., news regarding the money supply, government and trade deficits, interest rates and so forth) from returns due to firmspecific events (e.g., a dividend announcement, merger talks, product introduction, earnings report and so on). The abnormal return constitutes only that portion of the actual return due solely to the firmspecific factors.

The simplest metliod of correeting for marketwide influences im an event study computes abnormal returns as the difference between the actual returns on a stock and the returns on a market index. The difference is typically referred to as a "net-of-market" return. ${ }^{54}$ While useful for many purposes, the net-of-market approach has one

\footnotetext{
51 See Brown \& Warner, supra note 37 (empirical analysis demonstrating the relative power of standard daily return event study methodologies with suggestions for remedying a host of potential problems).

52 Fama, supra note 5, at 44-45.

53 Brown \& Warner, supra note 37, at 25.

54 The net-of-market return approach assumes that for a given percentage increase (decrease) in the market, the price of a given stock increases (deereases) by this same percentage.
} 
shortfall: it fails to account for the fact that individual stocks react differently to changes in overall economic conditions.

Simple regression analysis inakes it possible to ineasure the sensitivity, called beta, of an individual firm's stock price to the moveinents of the inarket as a whole. ${ }^{55}$ Suppose a firm with a beta of 1 experiences a stock price increase of $11 \%$ and that during the same period the inarket goes up by 5\%. The beta adjusted (and net-of-market) return to the firm is $6 \%$ (because the predicted return based on inarket inovements is $5 \%$ ). Similarly, suppose a firm with a beta of 1.2 experiences a stock price increase of $10 \%$ and that during the same period the inarket increases by $5 \%$. Here the predicted return based on market movelnents is $6 \%(5 \% \times 1.2)$; the beta adjusted return is $4 \%$, and the net-of-market return is $5 \%$.

As a practical matter there is generally hittle difference between beta adjusted, net-of-market, and even unadjusted returns when the stock's return is large relative to the inarket return and the event period is short. There are situations, however, where adjusting for the market (and the method of adjusting for the inarket) can have a significant impact on the estiunation of the abnorinal returns; event study methodology allows litigants to distinguish the moveinent due to the inarket. The most typical case occurs when the researcher estimates abnornal returns over a long window. For example, correcting for changes in overall market conditions might arise in securities litigation when estimating damages from misleading stateinents wliere the misleading nature of tlie statements was revealed over time. ${ }^{.6}$

Nowhere in the Securities Acts does the importance of using event study inethodology to account for overall inarket inovements mamfest itself more clearly than in the language of Section 11 of the Secur-

55 The researcher uses a control period (typically 150 days) ending some time (usually 20 days) before the event and estimates an equation explaining the firm's return as a function of the market return. The coefficient on the market return is beta. For example, a beta of 1.2 implies that a firm's stock price imcreases (or decreases) on average $1.2 \%$ when the market imcreases (or decreases) 1\%; similarly, a beta of 1 predicts that a firm's stock price will move on average the same as the market as a whole.

56 Note that in declining markets, the plaintiff has an incentive to focus attention on this distinction because filtering out the downward effect of the general market decline increases his damage award. This would be true, however, ouly if the misstatement were overly good news; if the misstatement were overly negative news, the situation would be reversed. Conversely, in a rising market, the defendant has an incentive to distinguish betwecn stock price movements caused by general market forces and movements caused by the misstatements. 
ities Act of 1933, which deals with civil liabilities for false and misleading registration statements. ${ }^{57}$ Generally, the Act provides that plaintiffs inay recover the difference between the ainount paid for the security and the value at the time the suit was broughti. ${ }^{58}$ If a sliare price fell for reasons otler than or in addition to the defendant's misconduct, lowever, dainages are offset accordingly. The Act states that if the defendant proves that "any portion or all such dainages represents other than the depreciation in value of sucli security resulting froin sucli part of the [false] registration stateinent, . . . sucli portion of or all such dainages sliall not be recoverable."59

Thus, it is clear that the litigants in securities fraud cases sometimes find it in their interests to distinguish the effects of marketwide from firm-specific factors on stock price. Event studies are uniquely suited to enable litigants to associate stock returns with particular events. We concentrate in the reinainder of this Article, lowever, on the simpler case where we do not aecount for market movements. We are primarily interested $\mathrm{m}$ demonstrating low to determine whetler a security return is large enough to be considered statistically different froin the normal return. When testing for materiality, we are interested on the impact on stock returns of a (potentially) inaterial misstatement during a sliort tine period, and corrections for inarket movements are thus usually unnecessary.

\section{Statistical Tests for the Significance of Abnormal Returns}

In the preceding material we have outlined a simple event study procedure that can be used to estimate the effect of the release of information on a stock return. In the fraud-on-tlie-market context this procedure could be used to estimate the size of the abnormal return associated witl a misstatement in order to determine wlietlier the misstatement distorted the price and thus whether it was material. In the following section we outline the procedure for testing the likelilood that a particular abnormal return occurred by chance. We

5715 U.S.C. $\S \S 77 \mathrm{a}, 77 \mathrm{k}$ (1988).

5815 U.S.C. $\$ 77 \mathrm{k}(\mathrm{e})$. Alternatively, if the stock were sold prior to suit in an effort to mitigate damages, the ineasure of damages would be the difference between the purchase price and the price at which the stock were sold. Finally, if the shares were sold after the suit but before judgment, the damages would be equal to this difference if it were less than the difference between the amount paid and the value at the timte the suit was brought. Id.

59 Id. 
explore, in other words, techniques for determining the level of confidence we can place in estimates of the abnormal return associated with a misstatement.

\section{a. Overview}

With statistical tests, researchers can determine the likelihood that abnormal stock returns at the time new information reached the market reflect assimilation by the market of the information or mere chance; evidence that the abnormal return was unlikely to have occurred by chance suggests materiality of the information. ${ }^{60}$ To test for such statistically significant returns, it is necessary to account for the usual volatility of returns, which varies across firms and over time. For example, the price movements (and thus returns) for a particular firm's stock may be large, yet this might be normal for a stock that generally exhibits high volatility. On the other hand, for less volatile stocks only a small change in return may indicate the occurrence of an unusual event. Thus, a thinly traded over-the-counter stock (or a new issue) with high volatility of returns might require a larger abnormal return than a widely traded stock with lower volatility of returns to enable the researcher to conclude that the return is statistically significant.

Statistical testing is used to determine the probability that a return differs from the normal return, or stated alternatively, that an abnormal return is significantly different froin zero. If under normal circumstances a certain size abnormal return is considered to be highly unlikely, its occurrence suggests that firm-specific news reached the market. It is possible to determine the extent to which a particular stock return was due to the random variation normally associated with the stock and the extent to which the movement was associated with a particular event (new information). If the release of the information is associated with a statistically significant abnormal return for the stock, then the evidence suggests the information was material.

A common method of assessing the statistical significance of an abnormal stock return around an event is to compare the return dur-

60 To test whether an omission is material, one need only wait until the omission is discovered and then measure whether the effect on share prices was statistically significant. The discussion following in the text is a simplified intuitive analysis. For a more complete discussion of statistical testing, the reader may consult a statistics book such as L. Ott, An Introduction to Statistical Methods and Data Analysis (3d ed. 1988). 
ing the event period to returns during a control period different froin the event period. The control period is used to determine both the normal return and volatility of the security. The test of statistical significance assigns a probability that the abnormal return occurred by chance, based on the coinparison with the control period.

So applied, the test for statistical significance can be used in at least two ways in securities hitigation. First, it can be used to determine materiality by deinonstrating the likelihood that a particular stateinent or omission affected the stock return. Second, tests for statistical significance can be used in damages calculations to estimate the justified level of confidence in results derived from event studies.

\section{b. Methodology for Statistical Tests}

Depending on the task at hand, the researcher may avail herself of a large number of statistical tests. ${ }^{61}$ In order to show how to test whether the daily return on a stock is different froin zero, ${ }^{62}$ the following discussion outlines the methodology for testing whether the mean of a sample is different froin the inean of the underlying population. In other words, we assume the normal daily stock return equals zero and test whether the actual return (i.e., the abnormal return) is different froin zero. ${ }^{63}$ We show that for some firms normal volatility is so great that ouly large returns are statistically different froin zero, whereas for other firms with less volatility smaller returns are statistically significant. We then derive estimates for various types of firms of the inagnitude of the stock returns that are statistically different froin (greater or less than) a inean of zero.

61 The choice of a particular methodology depends on a host of factors, most importantly the specific question asked. Other factors include the sample size, the characteristics of the sample, and the nature of the underlying population. For examples of different statistical tests to deal with different situations in event studies, see Brown \& Warner, supra note 37; Henderson, supra note 37.

62 Historically, the average daily return on a stock is slightly positive but extreinely sinall. See, e.g., Fama, supra note 5, at 37 (average daily return on stocks is .039\%).

63 The test outlined in the text following this note probably differs from the test a researcher would actually use to test the materiality of a stock price inovement under the fraud-on-themarket theory but is intended to show the utility of statistical testing for deinonstrating materiality. The researcher instead would use the past normal returns and volatility of the returns of the actual security under evaluation. Further, the type of statistical test employed inay vary depending on the inethod used to calculate abnormal returns; for example, the researcher would use a slightly different test if accounting for market movements in calculating abnormal returns. 
The conventional measure of variation in data is the standard deviation, which measures the dispersion in a variable around its average value. More formally, the standard deviation of a sample of data for a variable is given by:

$$
s=\sqrt{\frac{\sum_{i=1}^{\mathrm{N}}\left(\mathrm{X}_{i}-\overline{\mathrm{X}}\right)}{\mathrm{N}-1}}
$$

where $X_{i}$ denotes the values of the observations of the variable, $\bar{X}$ is the average or mean value of $X$, and $N$ equals the number of observations.

The formula indicates that the greater the variation of the values of $X_{i}$ from $\bar{X}$, the larger the standard deviation. ${ }^{64}$ Thus, for example, if all values of $X_{i}$ were identical, there would be no dispersion, and the standard deviation would be zero. That is, the sum of the deviations of $X_{i}$ around $\bar{X}$ would be zero. The term $\left(X_{i}-\bar{X}\right)$ is squared to avoid negative and positive deviations from canceling each other out. Division by $\mathrm{N}-1$ adjusts for the number of observations in the sample; without the $\mathrm{N}-1$ term, the statistic would always increase with an increase in the number of observations in the sample though the actual dispersion might be declining. Finally, taking the square root produces a measure of dispersion in terms of umits of the data, instead of umits of squared deviations. ${ }^{65}$

Many statistical tests assume the data (the $\mathrm{X}_{\mathrm{i}} \mathrm{s}$ ) are symmetrically distributed around the inean and not concentrated about the extreine values (outhers). The graphical representation of this symmetry is the familiar bell shaped curve. A stronger assumption than symmetry is that the data are distributed normally. ${ }^{66}$ The normal distribution has certain properties that inake it desirable for statistical testing; specifi-

\footnotetext{
64 For a more mathematical derivation, see L. Ott, supra note 60 , or any standard statistical text.

65 The standard deviation squared is the variance. Normally, researchers prefer the standard deviation to the variance because the standard deviation is measured in the same units as the data.

66 The assumption of a normal distribution is used in many statistical tests. The mathematical basis for this is a series of proofs from mathematical statistics called the Central Limit Theorems, which prove that in many cases such distributions are normal or approximately normal. For example, one Central Linit Theorem relevant to our discussion posits:
} 
cally, a normal distribution can be fully characterized merely by its mean value and its standard deviation. Although stock returns are actually not distributed normally, researchers have shown that the normal distribution is a good approximation for event study estimations. ${ }^{67}$

An example best illustrates the application of this methodology. Suppose a company's daily stock price return over the past fifty years is distributed normally with a mean of $0 \%$ and a standard deviation of $2 \%$. On January 20, 1991, llowever, the company's stock price mcreases $4 \%$. What is this return im terms of standardized units? The deviation of $4 \%$ from $0 \%\left(\left(\mathrm{X}_{\mathrm{i}}-\overline{\mathrm{X}}\right)\right)$ is $4 \%$, im units of the data; dividing $4 \%$ by the standard deviation of $2 \%$ produces a value of 2 . Thus, the $4 \%$ stock return on January 20 lies 2 standard deviations above the average daily return. Similarly, a return of $-3.0 \%$ would lie 1.5 standard deviations below the average return of $0 \%$.

More formally, the nuniber of standard units ("Z") for an observation in a normal distribution is given by:

$$
Z=\text { (value }- \text { mean) / standard deviation. }
$$

A normal distribution is useful in statistical testing because it enables us to make inferences about the probability that a certain outcome will occur. For example, for a normally distributed randoin variable, the probability is approximately $68.3 \%$ that a randomly selected value will be within one standard deviation of the mean; conversely, there is ouly a $31.7 \%$ chancc that a randomly selected value will not be within one standard deviation of the mean. Similarly, the probability is approximately $95.5 \%$ that a randomly selected value will be within two standard deviations of the mean, leaving only a $4.5 \%$ chance that it will not be within two standard deviations of the mean. Relatively few observations are over three standard deviations

If random samples of $n$ measurements are repeatedly drawn from a population with a finite mean $\mu$ and a standard deviation $\sigma$, then, when $n$ is large, the relative frequency histogram for the sample means (calculated from the repeated samples) will be approximately normal (bell-shaped) with mean $\mu$ and standard deviation $\sigma / \sqrt{n}$. (Note: The approximation becomes more precise as $n$ increases).

L. Ott, supra note 60 , at 109.

67 "The non-normality of daily returns has no obvious impact on event study methodologies." Brown \& Warner, supra note 37 , at 25 . With small sample sizes, the researcher often uses a $t$ distribution for the tests rather than a normal one. For sample sizes greater than 30, a t distribution is approximately the same as a normal. See L. Ott, supra note 60 , at 152 . 
from the mean; the probability is approximately $99.7 \%$ that random selection will result in a value within three standard deviations of the mean.

The application of these properties to lypotliesis testing is straightforward. We first establisl1 a null hypothesis, rejection of whicl1 affirms the research lypothesis we are interested in testing, in this instance whether an observation that has occurred is drawn from a certain normal distribution of inean $u$ and standard deviation $\sigma$. If the observation is inore than a certain specified number of standard deviations away froin the mean, we reject the null liypothesis that the observation is drawn froin the distribution with inean $u$ and standard deviation $\sigma$ and accept the alternative (research) liypotliesis that the observation is not from the distribution witli mean $u$ and standard deviation $\sigma$. In other words, there is something different about this observation.

Let us return to the company with the $4 \%$ stock price increase on January 20, 1991. A moveinent of that inagnitude (4\%) is rare sincc it lies two standard deviations away froin the inean daily return of $0 \%$ : we would expect to see this firm's stock price increase by $4 \%$ (or decline by $4 \%$ ) only $5 \%$ of the time. Whether we consider the $4 \%$ increase statistically different from zero depends on the level of significance we choose for our statistical test.

Researchers use decision rules to determine whether a given value is significantly different from the inean. Generally, values outside of 1.96 standard deviations from the inean are considered significantly different from the mean, because there is only a $5 \%$ chance that a randomly selected value will be over 1.96 standard deviations froin the inean. Sometimes the decision rule is less stringent. For example, the probability is about $90 \%$ that a randomly selected value will be less than 1.67 standard deviations froin the mean. Therefore, inany researchers characterize deviations greater than 1.67 standard deviations as significantly different from the inean. Soinetimes the decision rule is more strimgent. For example, there is only a $1 \%$ chance that a value will be more than 2.58 standard deviations from the;mean, and a researclier could determine that for the purposes of her test, only values exceeding 2.58 standard deviations would be considered significantly different from the mean.

The choice of the level of significance involves a tradeoff between two types of errors and indeed resembles the tradeoff between the two 
types of mistakes the criminal justice system can make. One type of error consists of finding an innocent person guilty; the other is finding a guilty person innocent. The first type of error can be minimized by setting the standard of proof required to find a person guilty very high. The criminal law, of course, does this by requiring proof beyond a reasonable doubt. But employing the higher standard makes it more likely that errors of the second type (finding a guilty person innocent) will occur.

The same tradeoff exists in hypothesis testing. By way of illustration, assume the null hypothesis to be that a criminal defendant is innocent. On the one hand is the mistake of concluding that an observation (criminal defendant) is not taken from a certain underlymg group (innocent people) when it is really from that group. This is called a Type 1 error. On the other hand is the mistake of concluding that the observation (criminal defendant) is from a group (innocent people) when it really is from a different group (guilty people). This is a Type 2 error. The researcher can reduce the probability of a Type 1 error by settimg a high level of significance, just as the criminal law sets a high standard of proof. For example, there is less chance of a Type 1 error if the researcher uses a $1 \%$ significance level than a $10 \%$ significance level. The tradeoff, however, is that while the higher significance level reduces Type 1 errors, it also mcreases the probability of Type 2 errors.

The researcher must decide which type of error is more important and choose a level of significance accordingly. We suggest choosing a significance level such that the probablity of a Type 1 error is less than 5\%; this is a standard level used by researchers in finance and economics. Nevertheless, there is no correct significance level, and calibrating the tradeoff is ultimately a value judgement based on the costs of imcorrectly rejecting the null hypothesis.

An alternative to accepting (or rejecting) the null hypothesis at a preset significance level is to report at what level of confidence the null hypothesis could be rejected. In the fraud-on-the-market theory context, the researcher would report at what significance level the null hypothesis that the abnormal return was equal to zero could be rejected. The court could then decide, based on the size and significance level of the abnormal return, whether the misstatement associated with that abnormal return was material. Note that the significance level of $5 \%$ we suggest, based on the level frequently used 
in einpirical economics, is a strict standard. It ineans that only $5 \%$ of the time will the researcher reject the null hypothesis when it is in fact true. This is a higher standard than the burden of proof standard set in a civil case, for example.

\section{EMPIRICAL GUIDELINES FOR DETERMINING MATERIALITY}

We provide in the following tables a gnide to the inagnitudes of daily stock price returns that are statistically different from a mean of zero for different types of firms. The Tables contain the standard deviations of daily returns for every stock histed on the New York Stock Exchange ("NYSE"), the American Stock Exchange ("ASE"), and the National Association of Securities Dealers Automatic Quotation System ("NASDAQ") ("over-the-counter" or "OTC" stocks). The standard deviations were calculated by averaging for all firms on each exchange the daily standard deviation of returns for each trading day in 1989. We divide the stocks in each of these markets into quartiles based on the value of the outstanding equity. ${ }^{68}$

The data in Tables 1-3 provide guidelines for determining whether a daily stock return is statistically different from the normal return of zero. A daily return statistically different froun zero suggests that soine firm-specific news reached the market on that day and can be used to show the materiality of that information. The numbers provide, however, only a rule of thumb. Firms within the different quartiles will have different volatility of returns (standard deviations of returns). For example, some sinall firms may have very stable stock returns whereas certain large firms (consider a firm with a high beta) nay have high volatility of returns. Additionally, the returns inay occur in a special period (such as the $1987 \mathrm{crash}$ ). Finally, these data are based on the standard deviation of actual returns, not abnormal returns.

Therefore, in an actual case the expert will examine the standard deviation of returns for the firm in question and use this standard deviation of returns to determine whether a misstateinent was material. It may in addition be useful to correct for overall market inovements. Occasionally the researcher may find herself unable to identify

68 We define equity value as the number of shares outstanding multiplied by the market price of those shares. 
TABLE 1

STANDARD DEVIATIONS OF THE DAILY RETURNS OF NYSE LISTED STOCKS FOR 1989

\begin{tabular}{|c|c|c|c|}
\hline & $\begin{array}{l}\text { Standard } \\
\text { deviation } \\
\text { of the } \\
\text { daily } \\
\text { return }\end{array}$ & $\begin{array}{l}\text { Daily return large } \\
\text { enough to be } \\
\text { considered } \\
\text { statistically different* } \\
\text { from the mean } \\
\text { (zero) (in percent) }\end{array}$ & $\begin{array}{l}\text { Firm size in } \\
\text { millions of } \\
\text { dollars (mean) }\end{array}$ \\
\hline $\begin{array}{l}\text { All NYSE } \\
\text { (1409 firms) }\end{array}$ & $2.09 \%$ & $\pm 4.10 \%$ & $\$ 1,907$ \\
\hline $\begin{array}{l}\text { 1st quartile } \\
\text { (352 firms) }\end{array}$ & $1.46 \%$ & $\pm 2.86 \%$ & $\$ 6,440$ \\
\hline $\begin{array}{l}\text { 2nd quartile } \\
\text { (352 firms) }\end{array}$ & $1.59 \%$ & $\pm 3.12 \%$ & $\$ 893$ \\
\hline $\begin{array}{l}\text { 3rd quartile } \\
\text { (352 firms) }\end{array}$ & $1.96 \%$ & $\pm 3.84 \%$ & $\$ 243$ \\
\hline $\begin{array}{l}\text { 4th quartile } \\
\text { (353 firms) }\end{array}$ & $3.34 \%$ & $\pm 6.55 \%$ & $\$ 57$ \\
\hline
\end{tabular}

* at the $5 \%$ level of significance

TABLE 2

Standard DeVIations of The DaIly Returns of ASE LISTED STOCKS FOR 1989

\begin{tabular}{lccc}
\hline & $\begin{array}{c}\text { Standard } \\
\text { deviation } \\
\text { of the } \\
\text { daily } \\
\text { return }\end{array}$ & $\begin{array}{c}\text { Daily return large } \\
\text { enough to be } \\
\text { considered } \\
\text { statistically different* } \\
\text { from the mean } \\
\text { (zero) (in percent) }\end{array}$ & $\begin{array}{c}\text { Firm size in } \\
\text { millions of } \\
\text { dollars (mean) }\end{array}$ \\
\hline $\begin{array}{l}\text { All ASE } \\
\text { (758 firms) }\end{array}$ & $3.12 \%$ & $\pm 6.12 \%$ & $\$ 145$ \\
$\begin{array}{l}\text { 1st quartile } \\
\text { (189 firms) }\end{array}$ & $1.98 \%$ & $\pm 3.88 \%$ & $\$ 494$ \\
$\begin{array}{l}\text { 2nd quartile } \\
\text { (189 firms) }\end{array}$ & $2.43 \%$ & $\pm 4.76 \%$ & $\$ 57$ \\
$\begin{array}{l}\text { 3rd quartile } \\
\text { (190 firms) }\end{array}$ & $2.96 \%$ & $\pm 5.80 \%$ & $\$ 21$ \\
$\begin{array}{l}\text { 4th quartile } \\
\text { (190 firms) }\end{array}$ & $5.11 \%$ & $\pm 10.02 \%$ & $\$ 6$ \\
\hline
\end{tabular}

* at the $5 \%$ level of significance 
TABLE 3

Standard Deviations of THE DAILY RETURNS OF NASDAQ STOCKS FOR 1989

\begin{tabular}{llcc}
\hline & $\begin{array}{c}\text { Standard } \\
\text { deviation } \\
\text { of the } \\
\text { daily } \\
\text { return }\end{array}$ & $\begin{array}{c}\text { Daily return large } \\
\text { enough to be } \\
\text { considered } \\
\text { statistically different* } \\
\text { from the mean } \\
\text { (zero) (im percent) }\end{array}$ & $\begin{array}{c}\text { Firm size in } \\
\text { millions of } \\
\text { dollars } \\
\text { (mean) }\end{array}$ \\
\hline $\begin{array}{l}\text { All NASDAQ } \\
\text { (3712 firms) }\end{array}$ & $3.72 \%$ & $\pm 7.29 \%$ & $\$ 98$ \\
$\begin{array}{l}\text { 1st quartile } \\
\text { (928 firms) }\end{array}$ & $2.28 \%$ & $\pm 4.47 \%$ & $\$ 338$ \\
$\begin{array}{l}\text { 2nd quartile } \\
\text { (928 firms) }\end{array}$ & $3.29 \%$ & $\pm 6.45 \%$ & $\$ 37$ \\
$\begin{array}{l}\text { 3rd quartile } \\
\text { (928 firms) } \\
\text { 4th quartile } \\
\text { (929 firms) }\end{array}$ & $4.23 \%$ & $\pm 8.29 \%$ & $\$ 12$ \\
\hline
\end{tabular}

* at the $5 \%$ level of significance

precisely when the relevant information reached the market. ${ }^{69}$ It will then be necessary to use an event wimdow of greater than one day and cumulate abnormal returns (cumulative abnormal returns). Nevertheless, under all these scenarios the procedure for calculating the statistical significance of abnormal returns (or cumulative abnormal returns) is very similar to what we outline below.

A researcher can use these standard deviations to determine the magnitude of a daily stock return for a given company that is large enough to be considered statistically different from zero, or more specifically, that is large enough so that the researcher can reject the nullhypothesis that the daily return is zero. We use the calculated standard deviations to report the size of the daily return for one stock that would be large enough so that the researcher could reject the hypothesis that that return is drawn from a distribution with a mean equal to zero at the $5 \%$ confidence level.

69 In some cases it will be easiest to use the day the fraudulent misstatement was released; in other cases it may be appropriate to use the day the fraud was revealed. The choice depends in part on the casier date to identify and the existence of confounding events at either time. 
Evidence that the release of the relevant information was associated with a statistically significant abnormal return indicates inateriality. The researcher first identifies the day when the pertinent news reached the market. If the daily return on the day of the news release day were greater (or less) than the appropriate return in Tables 1-3, it could be considered statistically different from the mean of zero at the $5 \%$ level of significance. In other words, she would reject the null hypothesis that the return was taken from a distribution with a mean of zero. Associating the statistically significant return with the release of the misstatement (or the revelation that an earher statement was a misstatement) imphes the statement was material. This would of course not prove the misstatement caused the abnormal return: proof is not a concept used in statistical testing because it is not possible to test with $100 \%$ confidence. At the same time, it would indicate to the researcher that she could not reject the hypothesis that the daily return differed from the mean. ${ }^{70}$

The standard deviations reported in the tables can also be used to determine the level of significance of an abnormal return: given an estimate of an abnormal return, the researcher could use the appropriate standard deviation and a table of the normal distribution im any statistics text to determine at what level of probability to reject the hypothesis that the abnormal return is equal to zero. For example, suppose the abnormal return for a third quartile NASDAQ stock associated with the release of a misstatement is $4.90 \%$. The relevant standard deviation is $4.23 \%$; the $\mathrm{Z}$ statistic is then $4.90 / 4.23$, or 1.16 . This is associated with a significance level of $25 \%$. In other words, an abnormal return of this size occurs randomly for a third quartile NASDAQ stock $25 \%$ of the time. ${ }^{71}$

As discussed earher, some stock prices are more volatile than others. Stock returns for larger firms tend to be less volatile than stock returns for smaller firms. In our presentation, therefore, we concentrate on a major variable related to this variation in volatility of stock returns, the size of the firm, and report the standard deviations of returns classified by this variable. As Table 1 indicates, a direct correlation exists between the size of a firm and the magnitude

70 If the researcher wanted a stricter decision rule, the reported standard deviations could be used to calculate the required daily return.

71 See Kritzman, What Practioners Need to Know About Uncertainty, 47 Fin. Analysts J. 17, 17-19 (March/April 1991) (deinonstrating such calculations). 
of the daily return considered statistically different from zero. For example, a firm in the fourth quartile of NYSE firms, i.e., a firm with an equity value of $\$ 57$ million, must register a change in share value of $6.55 \%$ or greater for that change to be statistically significant. By contrast, a firm in the first quartile need register a stock return of only $2.86 \%$ for it to be considered significant.

Differences in volatility among securities may be what the Supreme Court was considering in Basic v. Levinson when it limited the fraudon-the-market theory to efficient markets. We can account for greater volatility in determining the statistical significance of a return, however. Another related factor affecting lower courts' interpretations of Basic is the nature of the exchange on which the security trades. For example, at least one federal district court has suggested that the overthe-counter market might not be an efficient market. ${ }^{72}$ But we can test for the significance of a return traded on NASDAQ as well. In fact, a eomparison of Tables 1 and 3 reveals that the returns of inany NASDAQ stocks are less volatile than many NYSE stock returns. ${ }^{73}$

Table 1 contains estimates of the average daily standard deviation for stock price returns of the 1409 common stocks traded on the NYSE during the entire year of 1989 (252 trading days). The average standard deviation is 0.0209 , or about $2.1 \%$. Thus, for NYSE stocks during 1989 , only $5 \%$ of the daily stock price movements are over 4.1\%. Table 1 also reports the average daily standard deviations for the 1409 NYSE stocks portioned into quartiles on the basis of size. The first quartile contains the largest 352 NYSE common stocks. The average value of the common stock equity is roughly $\$ 6.4$ billion. The average standard deviation of the stock price returns is $1.46 \%$, sinaller than for the average NYSE stock. Thus, a stock price movement of at least plus (or mmus) $2.86 \%$ is statistically different from the mean for these larger NYSE stocks. In a simple example, the price of IBM stock does not have to change much in percentage terins for the move to be statistically significant. The standard deviation for the second quartile is roughly $1.6 \%$ and about $2 \%$ for the third quar-

72 Epstein v. American Reserve Corp., No. 79 C 4767 (N.D. Ill. filed Apr. 21, 1988) (LEXIS, Genfed library, Courts file).

73 We have concentrated on stock returns because data for stocks is easily accessible and most security fraud cases involve stocks. A similar analysis could, however, be performed for securities such as bonds. The researcher would determine the standard deviation of returns for the bonds and use this im tests for statistical significance of the return under examination. 
tile. For the fourth quartile, where the average value of the common equity is only $\$ 57$ million, the average daily standard deviation is $3.34 \%$. For these smallest stocks, prices wonld have to move approximately $6.55 \%$ for the movement to be considered significantly different from the mcan of zero. These data indicate that as the size of the firm decreases, volatility tends to increase. Thus, smaller firms must experience greater stock returns for those returns to be considered statistically significant.

Tables 2 and 3 provide similar data for ASE firms and NASDAQ firms, respectively. The average daily stock return standard deviation for the 758 ASE stocks is $3.1 \%$, roughly $50 \%$ greater than for the average NYSE stock. Thus, for the average ASE firm, the stock return would have to be $6.12 \%$ for the researcher to conclude it was significantly different froin zero. The average daily standard deviation for the 3,712 NASDAQ stocks is roughly 3.7\%, requiring a 7.29\% stock price inoveinent for significance at the 5\% level. The greater stock price volatility for the ASE and especially the NASDAQ is due largely to firm size effects. Whereas the average value of NYSE stocks is $\$ 1.9$ billion, the average value of ASE stocks is $\$ 145$ million, and the average value of NASDAQ stocks is $\$ 98$ million. Also, within the classes of ASE and NASDAQ stocks, sinaller firms have proportionately larger standard deviation of returns. For example, the average standard deviation for the smallest quartile of NASDAQ stocks is $5.1 \%$. Thus, for these low market value stocks (average valuc of $\$ 2.9$ million), a daily stock return of about $10 \%$ is necessary for the moveinent to be considered significantly different from the incan.

In addition to variations in stock return standard deviations across firms, there is variation over time. Table 4 reports the average daily standard deviation for the S\&P 500 Index yearly froin 1963 through 1989. The daily standard deviation of the S\&P 500 has ranged from as low as $0.33 \%$ in 1964 to $2 \%$ in 1987 (due to the crash). ${ }^{74}$ The year 1989 appears typical, and we suggest that the 1989 data in Tables 1-3 provides a particularly helpful guide.

74 See Mitchell \& Netter, Triggering the 1987 Stock Market Crash: Antitakeover Provisions in the Proposed House Ways and Means Tax Bill?, 24 J. Fin. Econ. 37, 4451 (1989) (discussing the increase in the standard deviation of the market around the 1987 stock market crash). 
TABLE 4

STANDARD DeViation OF THE DAILy RETURN ON THE S\&P 500 INDEX

\begin{tabular}{ccc}
\hline Year & Observations & $\begin{array}{c}\text { Standard } \\
\text { Deviation }\end{array}$ \\
\hline 1963 & 251 & .0054 \\
1964 & 253 & .0033 \\
1965 & 252 & .0043 \\
1966 & 252 & .0074 \\
1967 & 251 & .0052 \\
1968 & $226 *$ & .0057 \\
1969 & 250 & .0063 \\
1970 & 254 & .0095 \\
1971 & 253 & .0066 \\
1972 & 251 & .0050 \\
1973 & 252 & .0100 \\
1974 & 253 & .0137 \\
1975 & 253 & .0098 \\
1976 & 253 & .0070 \\
1977 & 252 & .0057 \\
1978 & 252 & .0079 \\
1979 & 253 & .0068 \\
1980 & 253 & .0100 \\
1981 & 253 & .0085 \\
1982 & 253 & .0120 \\
1983 & 253 & .0084 \\
1984 & 253 & .0080 \\
1985 & 252 & .0064 \\
1986 & 253 & .0093 \\
1987 & 253 & .0200 \\
1988 & 253 & .0108 \\
1989 & 252 & .0080 \\
\hline
\end{tabular}

* There are fewer trading days in 1968 because the NYSE did not trade on Wednesdays in 1968.

While these data provide only guidelines indicating the importance of information that has affected a stock return, at a minimuin the data provide a starting point for determining whether it would be useful to estimate the standard deviation of returns for the firm under study. Barring such a detailed study, these data provide better evidence on the importance of information associated with a stock return than any 
ad hoc theorizing about the efficiency of a market and the materiality of a piece of information.

In any event, the Supreme Court's distinction between shares that trade in efficient markets and shares that trade in mefficient markets should be of no consequence to litigants pursuing causes of action under the fraud-on-the-market theory: first, a better distinction than efficiency is the degree of volatility; second, after controlling for volatility, experts can determine the effects on share prices of fraudulent activities. In sum, there is no coherent reason for shareholders who invest in the stock of a thinly traded company that has volatile returns to be deprived of the benefits of the fraud-on-the-market theory.

\section{CONCLUSION}

In Basic v. Levinson the Supreme Court adopted the fraud-on-themarket theory for securities that trade in efficient markets. The Court $\mathrm{m}$ its holding rehed im part on the research findings of financial economists who have shown that im a wide variety of situations securities prices react very quickly to the release of new information. Unfortunately, by entertaining questions of efficiency, the Court overcomphcated its inquiry. There is disagreement among financial economists about the meaning of efficiency, how to test for it, and what the results of these tests mean. It is simply too complex to determine in a securities fraud case whether the presumption of rehance on the imtegrity of the market price is justified on the basis of the existence of an efficient market. Fortunately, this inquiry is also unnecessary.

We have argued that courts need not consider whether a security trades im an efficient or mefficient market; rather, courts should examine whether a misstatement caused a security to trade at an artificially high or low price. The inquiry devolves then into whether and how rapidly the market responded to the alleged misstatement. Financial economists can answer this question. As a result, courts may avoid the almost impossible task of identifymg efficiency and concentrate imstead on the relatively simple task of determining the stock return associated with a misstatement and whether it is statistically siguificant. If so, the court should conclude that the misstatement distorted the market price-that it was material-and presume rehiance. The legal system should not withhold redress from an imjured plamtiff simply because he owns the security of a corporation traded in a market considered by some court to be "mefficient." 
HeinOnline -- 77 Va. L. Rev. 10501991 